\title{
Recruitment Criteria and Training in Human Resources Development: A Case Study of Women Office Workers at an Institution of Higher Education in Saudi Arabia
}

\author{
SORAYA W. ASSAD \\ Assistant Professor \\ Department of Sociology \\ Faculty of Arts and Humanities \\ King Abdul-Aziz University, Jeddah, Saudi Arabia
}

( Received 20.8.1420H, and Accepted 24.2.1421H )

\begin{abstract}
This study examines employee recruitment criteria and training opportunities, uses a sample of 185 Saudi women office workers. It was found that the majority of the employees had a bachelor's degree, but had no formal qualification in administration, had no experience in similar jobs, did not do jobs which corresponded to their educational major, and felt that their jobs did not make use of their skills and abilities. Many of them also seemed to be underemployed since not all lower level administrative jobs necessarily required a bachelor's degree. It was also found that training programs were offered to employees, and the majority who attended indicated that the training was valuable. On the other hand, the majority of the respondents who received training attended only one training program and were unable to apply what they have learned. Almost half of the employees had never attended any form of training program. More than three fourth have not been offered training on any regular basis. On the basis of the previous findings recommendations are proposed.
\end{abstract}

One approach to measuring organizational effectiveness favored by managerial constituencies has been to look at the performance of individuals within the organization (Cummings and Schwab 1973:1-4). One criterion of effective organization is the efficiency of its personnel, since the productivity of an organization is usually affected by the performance of its participants. Studies have shown that individual performance is influenced among other factors by qualifications and the training they received. (Lawler 1973; Schoen and Durand 1979; Al-Sadhan 1982; Ghoseh 1983; Nash 1985; Russell et al.1985; Abdulrahman 1987; Al-Arawi 1987; Comstock 1987; Moore 1987; Al-Husseiny 1990; Bittel 1990; Al-Awwad 1991; AlHammad and Assaf 1996; Saks 1996; Borman and Hedge 1997; Weiss 1997.) 
Pursuit of development programs in Saudi Arabia has enlarged the size of organizations and increased their authority and functions. New organizations have also been created to implement the objectives and programs of the developing nation. These organizations seem to suffer from a set of administrative problems at the structural and the behavioral levels, which have been identified by such authors as Al-Awaji 1971; Al Sabhan 1972; Tawati 1976; Murshid 1978; Dhaher 1979; Al- Sadhan 1980; AlHegelan et al. 1985, 1987; Bukhary-Haddad 1986; Jreisat 1988, 1991; Assad 1989; AlAwwad 1991; and Al-Saeeri 1993.

Structural problems include: over centralization of authority, functional overlapping, overstaffing, red tape, absence of well-defined job responsibilities, inadequate communication, workers given assignments which may differ from workers educational background and job training, shortage of adequately trained personnel and, last but not least inadequate incentive system.

Problems at the behavioral level include: ineffective use of working hours, work completion delays, inadequate responsiveness to the public, low desire for hard work and responsibilities, and low employee performance. These deficiencies which reduce organizational effectiveness have been found to exist in academic as well as other organizations (Jammaz 1973; Assad 1977, 1983; Youssef 1981; Rawaf 1990, Al.Husseiny 1990) and have been found to have an adverse effect on women employees in particular (Rawaf 1990, Al.Husseiny 1990).

Prevailing cultural values in Saudi Arabia do emphasize competence and diligence at work, and the government is engaged in an intensive effort to maximize managerial effectiveness and improve worker performance. This has been reflected in the main objectives of the Fifth National Development Plan (1990-1995) and the current Sixth National Development Plan (1995-2000). Both Development Plans emphasize employment on the basis of merit, providing training programs, and establishing committees to study and reorganize government organization.

\section{The Purpose of The Study}

This study is of an exploratory nature. It focuses on Saudi women office workers and their perception of the suitability of the recruitment criteria and what training opportunities are available to them, which will be examined in the context of their socio-economic background characteristics.

Comparison will be made between permanent and contract employees with regard to their perception of the recruitment criteria and training opportunities. In conclusion recommendations for improvement will be proposed.

In the present study recruitment criteria refer to whether or not: a) employees perceive that their job corresponds with their educational qualifications, b) they have previous experience with the same type of work as their present job, and c) they think their job makes use of their skills and abilities. Training opportunities refer to whether or not they have attended training in connection with their job and, if so,: a) how frequently, b) how valuable it proved to be, and c) whether or not they were able to apply what they have learned through training. 


\section{Importance of The Study}

One of the most important elements in the development process is the individual which requires matching his/her job with educational qualifications, previous job experience, skills and proper training to ensure productivity. The study provides a better understanding of the working environment for women in Saudi Arabia. It summarizes information on how recruitment occurs and what training opportunities are available to women. It identifies the factors that may have an adverse effect on employee performance. It yields new insights into possibilities for future research on job performance as related to employee qualifications and training.

\section{Recruitment Criteria}

\section{Literature Review}

Generally speaking, an organization is viewed to be effective if its members were employed in positions which match their abilities, qualifications, and experience. In the past, the emphasis has been put on the desirability of specializing jobs to obtain higher productivity (Cummings and Schwab 1973:73). Selecting the right employee for the job may thus be the single best thing a manager can do in the entire employment cycle to ensure productivity (Nash 1985:35). Other view job performance as a function of both ability and motivational factors (Lawler 1973:8), (Nash 1985:40-41), and (Borman and Hedge 1997:300)

Schoen and Durand (1979:214) point out that "It is a great waste of human resources to utilize a person at less than his or her skill." It is also a great waste of human resources to employ a person on a job that does not match his or her skills, abilities, or interests. According to human capital theory, Kostiuk and Follmann (1989:130) indicate that education and experience enhance productivity. Recruitment, in the past has concentrated on characteristics of job seekers that presumably signal positive labor market information to employers (Bills 1990:23). Foremost among these have been educational credentials and years and type of work experience. Literature on job performance is paying increased attention to the relationships between ability, personality, job knowledge, technical proficiency, and work performance.

Arab researchers, e.g., Al-Sadhan (1982:19) and Al-Arawi (1987:14) have also found that lack of professionalism among employees is partly due to employment of persons on jobs that do not match their skills and abilities. Others have emphasized the importance of selecting people who can contribute to high employee productivity and satisfaction (Ghosheh 1983:37), (Abdulrahman 1987:122), and (Al-Awwad (1991:72). To obtain high performance from employees, organizations should give adequate consideration to hiring and employing qualified persons for jobs to be done rather than randomly matching people with jobs (Al-Awwad 1991:72). According to Al-Hammad and Assaf (1996:45), the improper selection of skilled labor affects the quality and productivity of maintenance workers.

\section{Traning Opprtunities}

By general consensus, training affects employee productivity and thus the effectiveness of the employing organization (Schein 1965, Miner 1969, Savas and Ginsburg 1973, Reilly 1979, Russell et al., 1985, Nash 1985, Moore 1987, Comstock 
1987, Bittel 1990, Al-Awwad 1991, Saks 1996, Weiss 1997). Schein (1965:34) emphasizes that members of an organization should be trained regularly to keep pace with rapid changes in knowledge, skills, and technology. Training is important to orient new employees; to teach specific knowledge, skills, and attitudes; and to provide opportunities for self-development. According to Miner (1969) and Moore (1987), training should enhance the person's performance and, in turn, improve the output of the organization. Similarly, Savas and Ginsburg (1973:81) state that to improve the performance and motivation of employees, training opportunities should be greatly increased. Nash (1985:84) also argues that training is important to productivity and that most people can be trained to be more productive. (Russell et al.1985:850) discusses several studies which have demonstrated that training can be effective at producing positive changes in individual behavior and job performance.

Comstock (1987:292) considers employee training essential to the overall success of any company which is dependent on the skills and abilities of its workers. Supervisors who train their workers well get better on-the-job performance. Welltrained workers require less supervision, because worker skills are increased by training, enabling supervisors to delegate tasks that they previously had to perform themselves. Training also results in improved interpersonal relationships between supervisors and workers. In addition, proper training prepares at least, one qualified employee who has the skills to take over the supervisor's job.

Bittle (1990:235) points out that in the absence of sound training, employees learn their jobs haphazardly, inaccurately, or not at all. Only through careful assessment of needs, systematic instruction, and responsible follow-up can a supervisor be confident that employees will learn how to perform their work in the most effective manner.

Al-Awwad (1991:83-84) agrees that staff training should be a fundamental concern of most administrations. Money and effort spent to develop employees' abilities and skills aim at achieving efficient and adequate work results to improve organizational effectiveness. Any deficiency in training will surely affect the productive abilities of employees and in turn the general productivity of an organization.

Saks (1996:429) found that the amount of training received by newcomers was significantly related to job satisfaction, commitment, intention to quit, ability to cope, and several measures of job performance.

Weiss (1997:3)shows that to maintain a high-level work products, a company must motivate and inoculate employees with the proper attitude and train them to respond appropriately. Training cannot be left to chance or to another employee who may be doing the job but is not trained to instruct a newcomer.

In Saudi Arabia, the importance of training government employees has been recognized. It is compulsory that all government agencies give such opportunities to all their employees (Al-Awwad 1991:94). However, authors such as Abdurrahman (1987) and Al-Awwad (1991:173) have indicated that Saudi Arabia still faces the same training problems as most developing nations due to shortages of manpower and particularly of qualified trainers, lack of effective training, the newness of practicing 
modern administration, and the rush to achieve fast development. Al-Sadhan (1982:19) and Al-Arawi (1987:14) both argue that one factor that adversely affects the performance of the Saudi employee is lack of training. Al-Husseiny (1990:184) suggests lack of training programs to prepare senior female administrators in the country as one factor that adversely affects their efficiency. Al-Awwad (1991:335) found out that the majority of the sample he surveyed had not been trained at all in ways relevant to their jobs.

\section{Study Method}

The study sample was drawn from one of the main institutions in the Kingdom of Saudi Arabia, which currently employ the largest number of teachers and administrators. All workers were included in the sample as the total size of the selected population was 185 Saudi women engaged in administrative work at a higher educational institution in Saudi Arabia. Job positions were general office workers, bookkeepers, counter clerks, file clerks, typists, librarian assistants, and secretaries. The sample included 104 permanent and 81 contract employees. Permanent employees are those hired on a permanent basis. They get paid according to the job grade level assigned to them. They are entitled to such government employment privileges as retirement pay, promotion, yearly bonus, ten days yearly of emergency leave, thirty days yearly of paid vacation, and paid sick leave for up to a year. Contract employees are those hired on a contract basis for six months. They get paid according to their qualifications. They are not usually entitled to such government employment privileges as retirement pay, promotion, yearly bonus, and emergency leave. However, they may receive social insurance for retirement. They are entitled to twenty days yearly of paid vacation and to paid sick leave for up to nine months. Years of work experience as contract employees are not considered in calculating benefits if the employee later acquires a permanent position with the government.

Questionnaires were administered in Arabic to the subjects at their work sites, during working hours, and in the presence of the researcher.

Part I of the questionnaire collects demographic data about the subjects, in the following areas: women's marital status, education, major, monthly income, years of work experience and employment type. Part II of the questionnaire includes a set of questions that would measure the following variables:

(1) recruitment criteria refer to the suitability of job placement as perceived by the workers. The variable was measured through questions on whether or not: a) they perceive that their job correspond with their educational major, b) they have previous experience with the same type of work as their present jobs, and c) they think that their jobs make use of their skills and abilities.

(2) Employees' perception of the adequacy of training opportunities. The variable was measured through questions on whether or not: a) they had attended any training programs in connection with their job and, if so, how many; b) they were offered training on the job on a yearly basis; c) they considered any training programs valuable, and d) whether or not they were able to apply what they had learned in training.

Findings are reported in terms of total frequencies and percentages. 


\section{Demographic Characteristics}

\section{Findings}

Table (1) shows demographic characteristics of the study population.

Table (1) Summary of Demographic Characteristics of the Study Population

\begin{tabular}{|c|c|c|c|c|c|c|c|}
\hline Factor & & \begin{tabular}{c|} 
Contract \\
Employees
\end{tabular} & $\%$ & $\begin{array}{l}\text { Permanent } \\
\text { Employees }\end{array}$ & $\%$ & Total & $\%$ \\
\hline \multirow[t]{2}{*}{ Marital status } & Married & 64 & 79.0 & 72 & 69.2 & 136 & 73.5 \\
\hline & Single & 17 & 21.0 & 32 & 30.8 & 49 & 26.5 \\
\hline \multirow[t]{2}{*}{ Educational level } & No college degree & 29 & 35.8 & 26 & 25.0 & 55 & 29.7 \\
\hline & College degree & 52 & 64.2 & 78 & 75.0 & 130 & 70.3 \\
\hline \multirow[t]{3}{*}{ Major } & Liberal art & 32 & 39.5 & 53 & 51.0 & 85 & 46.0 \\
\hline & No major & 29 & 35.8 & 26 & 25.0 & 55 & 29.7 \\
\hline & Administration & 20 & 24.7 & 25 & 24.0 & 45 & 24.3 \\
\hline \multirow[t]{2}{*}{ Monthly income } & Less than 6,000 Saudi Riyals & 81 & 100.0 & 40 & 38.5 & 121 & 65.4 \\
\hline & 6,000 Saudi Riyals and more & 0 & 0 & 64 & 61.5 & 64 & 34.6 \\
\hline \multirow[t]{2}{*}{ Age } & Less than 35 & 63 & 77.8 & 42 & 40.4 & 105 & 56.8 \\
\hline & 35 and more & 18 & 22.2 & 62 & 59.6 & 80 & 43.2 \\
\hline \multirow{3}{*}{$\begin{array}{l}\text { Years of } \\
\text { work experience }\end{array}$} & $1-5$ & 71 & 87.6 & 19 & 18.3 & 90 & 49.0 \\
\hline & $6-10$ & 5 & 6.2 & 21 & 20.0 & 26 & 14.0 \\
\hline & More than 10 & 5 & 6.2 & 64 & 61.5 & 69 & 37.0 \\
\hline \multicolumn{2}{|c|}{ Total responses for each factor } & 81 & & 104 & & 185 & \\
\hline
\end{tabular}

The majority, 136 (73.5 percent), were married. Most respondents, 130 (70.3 percent), had a bachelor's degree. The majority, 140 (75.7 percent), had no formal qualification in administration. Most, 121 respondents (65.4 percent), earned less than 6,000 Saudi riyals per month $(\$ 1.00=3.75$ Saudi riyals $)$; only 64 respondents $(34.6$ percent) earned this amount or more. All 81 contract employees earned less than 6,000 Saudi riyals per month, while only 40 permanent employees ( 38.5 percent) earned less than this amount. Most respondents, 105 (56.8 percent), were under the age of 35;80 respondents (43.2 percent) were 35 years old or over. Among contract employees, 77.8 percent were under the age of 35 , while only 40.4 percent of permanent employees were that young.

With respect to number of years of work experience, 49.0 percent had worked five years or less, 14.0 percent had worked between six and ten years, and 37.0 had worked more than ten years. Contract employees had even less work experience than permanent employees; 87.6 percent of the contract employees had worked no more than five years, while 61.5 percent of the permanent employees had worked more than ten years.

\section{Perceived Adequacy of Recruitment}

In order to assess recruitment criteria, the following factors were examined: 1) the employees' educational level, 2) her field of study, 3) the extent to which she perceived that her job corresponded with her educational major, 4) her previous experience with the same type of work as her present job, and 5) whether she perceived that her job made use of her skills and abilities. Table 2 summarizes the general descriptive findings concerning this cluster of variables. 
Table (2) Descriptive Findings Related to Recruitment Criteria

\begin{tabular}{|c|c|c|c|}
\hline Educational Level & With Bachelor's degree & Without Bachelor's degree & Row Total \\
$\%$ & 130 & 55 & 185 \\
$\%$ & 70.3 & 29.7 & 100.0 \\
\hline Field of specialization & Administration & Other & \\
& 45 & 140 & 185 \\
\hline Job corresponds with & 24.3 & 75.7 & 100.0 \\
education & Yes & No & 185 \\
$\%$ & 68 & 63.2 & 100.0 \\
\hline Previous experience with & 36.8 & No & 185 \\
the job & Yes & 126 & 100.0 \\
$\%$ & 59 & 68.1 & \\
Job makes use of & 31.9 & No & 184 \\
employee skills & Yes & 97 & 100.0 \\
\hline
\end{tabular}

Assuming that education enhances task performance, the employees are impressively qualified, even overqualified in many cases, with the large majority, 130 (70.3 percent), having a Bachelor's degree, including 75 percent of permanent and 64.2 percent of contract employees.

Table (3) shows that the large majority of respondents, 140 employees (75.7 percent), had not specialized in administration studies; 41 (22.1 percent) had specialized in public or business administration, but only four (2.2 percent) had specialized in educational administration.

Table (3) Frequency Distribution of Field of Specialization by Employment Type

\begin{tabular}{|c|c|c|c|}
\hline Field of Specialization & \multicolumn{3}{|c|}{ Employment Type } \\
\hline $\begin{array}{c}\text { Without major (Diploma in } \\
\text { secretarial work/high school or less) }\end{array}$ & 29 & 26 & Total \\
$\%$ & 35.8 & 25.0 & 55 \\
\hline Liberal Arts & 32 & 53 & 29.7 \\
$\%$ & 39.5 & 51.0 & 85 \\
$\%$ & 20 & 21 & 46.0 \\
\hline Administration (Business or Public) & 24.7 & 20.2 & 41 \\
\hline Educational Administration & 0 & 4 & 22.1 \\
\hline Column Total & 0.0 & 3.8 & 4 \\
& 81 & 104 & 185 \\
\hline
\end{tabular}

The low percentage of both permanent and contract employees with administrative skills and knowledge suggests that their job performance may be adversely affected. Al-Saigh (1986:29) points out that most graduates in Arab countries want to be government employees in administrative posts but lack administrative skills and knowledge, which influences their performance negatively. Al-Awwad (1991:162) argues similarly.

Respondents were also asked whether their jobs matched their educational majors. The majority, 117 (63.2 percent), reported that they did not (Table 4). These results recall Al-Zamel's (1983:27) finding; 73 percent of his sample reported that their jobs matched their educational majors only to some or a small extent. 
Table (4) Perceived Correspondence of Job with Major by Employment Type

\begin{tabular}{|c|c|c|c|}
\hline Job Matches Major & \multicolumn{3}{|c|}{ Employment Type } \\
\hline & Contract Employees & Permanent Employees & Total \\
\hline Yes & 25 & 43 & 68 \\
$\%$ & 30.9 & 41.3 & 36.8 \\
\hline No & 56 & 61 & 117 \\
$\%$ & 69.1 & 58.7 & 63.2 \\
\hline Total & 81 & 104 & 185 \\
& & & 100.0 \\
\hline
\end{tabular}

Table (4) also shows that contract employees were more likely to believe that their job did not correspond with their major (69.1 percent) than permanent employees were (58.7 percent).

As Table (5) shows, when respondents were asked whether they had had previous experience with the same type of work as they were doing on their present job, more than two-thirds (68.1 percent) reported that they had not. The same Table also indicates that fewer contract employees (21.0 percent) than permanent employees (40.4 percent) indicated that they had had similar previous experience.

Table (5) Previous Relevant Job Experience by Employment Type

\begin{tabular}{|c|c|c|c|}
\hline $\begin{array}{c}\text { Previous Relevant Job } \\
\text { Experience }\end{array}$ & \multicolumn{3}{|c|}{ Employment Type } \\
\hline & Contract Employees & Permanent Employees & Total \\
\hline Yes & 17 & 42 & 59 \\
$\%$ & 21.0 & 40.4 & 31.9 \\
\hline No & 64 & 62 & 126 \\
$\%$ & 79.0 & 59.6 & 68.1 \\
\hline Total & 81 & 104 & 185 \\
& & & 100.0 \\
\hline
\end{tabular}

Finally, more than half of the employees (53.0 percent) reported that their jobs did not make use of their skills and abilities (see Table 6). Contract employees were more likely to report this (60.5 percent) than permanent employees were (47.1 percent).

Table (6) Perception that Job Makes Use of Skills and Abilities by Employment Type

\begin{tabular}{|c|c|c|c|}
\hline $\begin{array}{c}|c| \\
\text { Job Makes Use of Skills and } \\
\text { Abilities }\end{array}$ & \multicolumn{3}{|c|}{ Employment Type } \\
\hline & Contract employees & Permanent employees & Total \\
\hline Yes & 32 & 55 & 87 \\
$\%$ & 39.5 & 52.9 & 47.0 \\
\hline No & 49 & 49 & 98 \\
$\%$ & 60.5 & 47.1 & 53.0 \\
\hline Total & 81 & 104 & 185 \\
& & & 100.0 \\
\hline
\end{tabular}

The shortage of qualified, trained Saudi personnel to support the country's rapid expansion of government activities may have been responsible for giving people assignments which differ from their educational specialization, skills, abilities, and previous job experience. Consequently, position descriptions may have had to be flexible concerning educational qualifications to accommodate the need to fill a greater number of positions than there have been applicants specifically trained for them. Managers also have been unable to be as demanding in their hiring standards as they 
might like, and have had to accept the fact that, consequently, employees may not perform up to expectations. In addition, hiring has not always been based on objective criteria; family and friendship relations are other important factors.

\section{Perceived Adequacy of Training Opportunities:}

In the present study, respondents were asked whether they had attended any training programs in connection with their job and, if so, how many; whether they were offered training on the job on a yearly or other basis; whether or not they considered any training programs valuable; and whether or not they were able to apply what they had learned through training. The general findings for this cluster of variables are summarized in Table (7).

Table (7) Summary of Respondents' Training Experience

\begin{tabular}{|c|c|c|c|}
\hline Training Experience & Yes & No & Row Total \\
\hline Attended Training & 103 & 82 & 185 \\
$\%$ & 55.7 & 44.3 & 100.0 \\
\hline Offered Training Yearly & 41 & 144 & 185 \\
$\%$ & 22.2 & 77.8 & 100.0 \\
\hline Training is Valuable & 87 & 16 & 185 \\
$\%$ & 84.5 & 15.5 & 100.0 \\
\hline Apply What is Learned in Training & 51 & 52 & 103 \\
$\%$ & 49.5 & 50.5 & 100.0 \\
\hline
\end{tabular}

The results show that 44.3 percent of the respondents (58.0 percent of contract and 33.7 percent of permanent employees) had never attended any form of training.

Respondents who said they were not able to attend training programs or were not able to apply what they learned in training were asked to give reasons for this. Reasons for not attending, listed in order of frequency, were: that they were not permanent employees (39.0 percent), that they had never been asked (25.6 percent), that others received favoritism (24.4 percent), and finally, lack of training programs offered during working hours (11.0 percent).

When respondents were asked how many training programs they had attended, of the 55.7 percent who indicated that they had attended training, over half, 51.5 percent, said that they had attended only one training program, while 22.3 percent said they had attended two training programs and 26.2 percent said they had been more than two training programs (see Table 8).

Table (8) Number of Training Programs Attended

\begin{tabular}{|c|c|c|}
\hline Number of Programs & Frequency & $\%$ \\
\hline 1 & 53 & 51.5 \\
\hline 2 & 23 & 22.3 \\
\hline 3 & 15 & 14.6 \\
\hline 4 & 8 & 7.8 \\
\hline 5 & 2 & 1.9 \\
\hline 6 & 2 & 1.9 \\
\hline Receiving Training & 103 & 100.0 \\
\hline Not Receiving Training & 82 & \\
\hline Total & 185 & \\
\hline
\end{tabular}


Table (9) shows the further breakdown that most contract employees, 76.5 percent, who received training attended only one training program, whereas only 39.13 percent of the permanent employees who received training attended one training program only. Among the permanent employees who received training 60.87 percent attended two or more training programs, while only 23.5 percent of the contract employees who received training attended two or more training programs.

Table (9) Number of Training Programs Attended by Employment Type.

\begin{tabular}{|c|c|c|c|c|}
\hline Number of Training Programs & \multicolumn{2}{|c|}{ Contract Employees } & \multicolumn{2}{c|}{ Permanent Employees } \\
\hline & $\mathrm{F}$ & $\%$ & $\mathrm{~F}$ & $\%$ \\
\hline 1 & 26 & 76.5 & 27 & 39.13 \\
\hline 2 & 4 & 11.8 & 19 & 27.54 \\
\hline 3 & 3 & 8.8 & 12 & 17.39 \\
\hline 4 & 1 & 2.9 & 7 & 10.14 \\
\hline 5 & - & - & 2 & 2.90 \\
\hline 6 & - & - & 2 & 2.90 \\
\hline Receiving Training & 34 & 100.0 & 69 & 100.0 \\
\hline Not Receiving Training & 47 & & 35 & \\
\hline Total & 81 & & 104 & \\
\hline
\end{tabular}

As Table (10) shows, a large majority, 77.3 percent, of the employees said that they did not receive training on a yearly basis. No large difference existed in this regard between contract and permanent employees.

Table (10) Offered Yearly Training by Employment Type

\begin{tabular}{|c|c|c|c|}
\hline Offered Yearly Training & Contract Employees & Permanent Employees & Total \\
\hline Yes & 18 & 24 & 42 \\
$\%$ & 22.2 & 23.1 & 22.7 \\
\hline No & 63 & 80 & 143 \\
$\%$ & 77.8 & 76.9 & 77.3 \\
\hline Total & 81 & 104 & 185 \\
& & & 100.0 \\
\hline
\end{tabular}

However, as Table (11) shows, 50.9 percent of permanent but only 40.7 percent of the contract employees said that they had been offered training within the last three years.

Table (11) Frequency of Training Programs Offered by Employment Type.

\begin{tabular}{|l|c|c|c|}
\hline Frequency & Contract Employees & Permanent Employees & Total \\
\hline Not Offered & 44 & 28 & 72 \\
$\%$ & 54.3 & 27.0 & 39.0 \\
\hline Once Every 4 - 5 Years & 4 & 23 & 27 \\
$\%$ & 5.0 & 22.1 & 14.5 \\
\hline Once Every 2 - 3 Years & 15 & 30 & 45 \\
$\%$ & 18.5 & 28.8 & 24.3 \\
\hline Once a Year & 15 & 20 & 35 \\
$\%$ & 18.5 & 19.2 & 19.0 \\
\hline Once Every Six Months & 3 & 3 & 6 \\
$\%$ & 3.7 & 2.9 & 3.2 \\
\hline Total & 81 & 104 & 185 \\
& & & 100.0 \\
\hline
\end{tabular}


When the 103 respondents who had attended training were asked whether the training they had received was valuable, 87 (84.5 percent) indicated that it was, while only 16 (15.5 percent) reported that it was not beneficial (see Table 12). Contract employees showed even greater tendency toward appreciating training than permanent employees.

Table (12) Perceived Benefit of Training by Employment Type

\begin{tabular}{|c|c|c|c|}
\hline Training Beneficial & Contract Employees & Permanent Employees & Total \\
\hline Yes & 30 & 57 & 87 \\
$\%$ & 88.2 & 82.6 & 84.5 \\
\hline No & 4 & 12 & 16 \\
$\%$ & 11.8 & 17.4 & 15.5 \\
\hline Total & 34 & 69 & 103 \\
& & & 100.0 \\
\hline
\end{tabular}

Nevertheless, when the 103 who had had training were asked whether they had applied what they had learned, more than half of them, 50.5 percent, reported that they had not. A higher percentage of the contract employees (60.0 percent) as compared with the permanent employees (46.6 percent) indicated that they had not applied what they had learned (see Table 13).

Table (13) Applied Training by Employment Type

\begin{tabular}{|c|c|c|c|}
\hline Applied Training & Contract Employees & $\begin{array}{c}\text { Permanent } \\
\text { Employees }\end{array}$ & Total \\
\hline Yes & 12 & 39 & 51 \\
$\%$ & 40.0 & 53.4 & 49.5 \\
\hline No & 18 & 34 & 52 \\
$\%$ & 60.0 & 46.6 & 50.5 \\
\hline Total & 30 & 73 & 103 \\
& & & 100.0 \\
\hline
\end{tabular}

Reasons given for not being able to apply training, in order of frequency, were: lack of office equipment and/or equipment in need of programming or maintenance, training program was not related to job, and application requires time and effort. Among respondents who said they were not able to apply training, office equipment problems were blamed by 45.7 percent, while poor relation between the training and the respondent's job was cited by 35.7 percent. The remaining 18.6 percent admitted that they were not willing to devote the time and effort necessary to apply what they have learned from training.

The findings show that the large majority of the respondents who received training, particularly contract employees, had received training infrequently, with the majority attending only one training program, and that the majority have been unable to apply what they have learned, often because office equipment did not permit it or because it seemed irrelevant to their jobs. Almost half of the employees had never attended any form of training program. More than three-quarters have not been offered training on regular basis. While the majority have indicated that they had attended training, more than half of them had attended only one training program. Contract employees, who constituted 43.8 percent of the total number of workers, had even less training; 58 percent had never attended a training program. Of those attending, over three-quarters attended only one training program. 


\section{Conclusion}

It was found that the majority of the employees had a bachlor's degree, but had no formal qualification in administration, had no experience in similar job, and did not do jobs which corresponded to their educational major. Therefore, not surprisingly, more often than not employees felt that their jobs did not make use of their skills and abilities. Many of them also seemed to be underemployed.

It may be stated also that training programs have been offered to employees and that the majority of those who attended indicated that training was valuable. On the other hand, it appears that most of the employees under investigation have not had adequate and appropriate training. Problems with training could be attributed to the organization itself, to the training programs offered, and to a lesser degree to the trainees themselves. Many employees have indicated that they have not formally received any on-the-job training when they joined the organization, they were usually told how to do their job informally by their colleagues and/or the supervisor. They have gained knowledge and skills by trial and error. They were not offered training on any regular basis; and the situation of contract employees, was even worse as they usually received little or no training; office equipment have made it difficult for trained employees to apply what they had learned. In addition, training programs have not been offered during working hours and were often not related to trainees' jobs. Last but not least, some employees have been unwilling to apply what they have learned, and some employees had even no desire to participate in training programs.

\section{Recommendations}

On the basis of the previous findings the following recommendation can be made.

\section{Recommendations for Recruitment}

(1) There is a need to recruit employees more appropriately to gain better job performance. Although the majority of the respondents have a Bachelor's degree, most have no formal qualification in administration, and less than half have high school secretarial or clerical training.

(2) Attention should be given to hiring persons who have a degree in administration, preferably educational administration, for jobs requiring such knowledge and skills.

(3) Consideration should be given to hiring persons with only high school secretarial or clerical training for jobs for which such training will suffice. Not all lower-level administrative jobs necessarily require a Bachelor's degree. The majority of the respondents are university graduates, they may be discontented and thus perform at a lower level because they are underemployed and bored with their jobs.

(4) The majority of the employees indicated that they had not had previous experience in similar jobs. Previous experience should be required of all new employees above the lowest echelons. Therefore, persons should be encouraged to work as volunteers to gain job experience while awaiting employment.

(5) The majority of the employees reported that their job did not correspond to their educational major. There is a need to match job with major as closely as possible. 
When respondents were asked what motivated them to work better, correspondence of job with major was ranked by them as the most important factor.

(6) More than half of the respondents indicated that their job did not make use of their skills and abilities. Employee skills and abilities should be carefully assessed before hiring.

(7) Attention should also be paid to matching job title with actual job. A number of respondents were frustrated because they considered a mismatch here an obstacle to their promotion.

(8) Emphasis should be put on interviews and written exams to select employees who reflect important criteria such as knowledge, skills, abilities, interests, and aptitudes.

(9) The direct supervisor should participate in the process of selecting new employees since this is the person who presumably knows the nature of the work to be done and the types of employees needed.

(10) More control should be exercised in selecting new employees to avoid giving priority to personal relationships which respondents said are still the primary factors in hiring. Favoritism de-emphasizes selecting "The right person for the right job" and hence will have a negative effect on organizational effectiveness.. Efficiency and productivity doubtless suffer as a result.

(11) Better attention should be given to contract employees since high percentages of them indicated that their job did not correspond with their educational major, they had had no similar previous job experience, and their job did not make use of their skills and abilities.

The Saudi government is understandably very concerned with replacing non-Saudi with Saudi employees, but even more important is that people be employed in positions which match their qualifications, fields of educational specialization, abilities, skills, interests, and prior job experience if better productivity is to be achieved.

In the process of creating a modern Saudi work force, educational programs should be concerned with matching individuals' interests, aptitudes, and abilities with their fields of study. In addition, educational policy and training programs should be concerned with acquiring needed new skills if they are to become successful participants in the global economy.

\section{Recommendations for Training}

Recommendation for the organization:

(1) Consideration should be given to offering contract employees equal opportunities to attend training programs. The need for this is especially evident when we consider that 75.3 percent of contract employees have no formal qualification in administration 69.1 percent reported that their job did not match their major, 79.0 percent indicated that they had had no previous similar job experience, and 60.5 percent felt that their job did not make use of their skills and abilities. 
(2) Employees should be given opportunity and incentives to use what they have learned so as to improve the effectiveness of the organization.

(3) More attention should be given to providing educational programs in administration in Saudi institutions. The Education and Labor Ministries should work together to make sure that sufficient numbers of appropriately educated graduates are being produced to meet the country's manpower needs. Incentives should be such as would attract students to study in fields in which manpower shortages exist.

(4) Employees should be provided the equipment they need to function more efficiently, and this equipment should be maintained in good operating condition. Computer operators and programmers are examples of manpower shortage fields that need to attract students.

(5) It is becoming increasingly important to improve linkage between education, training programs, and market demands to achieve better coordination between producers and users of skills.

\section{Recommendation for training programs}

(1) Employees should have more relevant training. Nearly half of all respondents have five years or less of work experience. The majority of the respondents have no formal qualification in administration, their job did not match their educational major, they do not have previous similar job experience, and they feel that their job does not make use of their skills and abilities. Less than half of the respondents have high school secretarial or clerical training.

(2) Training should be mandatory and systematic to keep pace with rapid changes in the organization of information and new computer applications.

(3) Training programs should be relevant to the jobs of those attending.

(4) There is a great need to train employees in certain skills, behavior, and attitudes, such as learning to prioritize work appropriately, getting work done fast without follow-up from the supervisor, staying in one's office during working hours unless absence is necessary and excused, helping inquirers in the order they arrive, referring inquirers to a person who can help them if the employee does not know the answer to a question, and giving accurate information. In brief, employees have to learn to behave according to work ethics and must be called to account if they fail to do so.

\section{References}

Abdulrahman, Osama (1987) "Petroleum Bureaucracy and the Problem of Development: An Introduction to the Study of the Administration of Development in the Oil Producing States in the Arabian Peninsula", Cyprus. Dar Alshabab.

Al-Arawi, Badria (1987). "Factors Contributing to Poor Working Habits", Civil Service Journal, 115, pp. 14-19.

Al-Awaji, Ibrahim (1971) Bureaucracy and Society in Saudi Arabia. Unpublished Doctoral Dissertation, University of Virginia.

Al-Awwad, Khalid (1991) Service Provision in Saudi Public Service Sector Organizations: An Open System Approach, Unpublished Doctoral Dissertation. University of Wales. 
Al-Hammad, A. and S. Assaf (1996) "Assessment of work Performance of Maintenance Contractors in Saudi Arabia", Journal of Management in Engineering, 12, No. 2, pp. 44-50.

Al-Hegelan, A. and M. Palmer (1985) "Bureaucracy and Development in Saudi Arabia", The Middle East Journal, 39, No. 1, pp. 48-68.

Al-Hegelan, A., M. Palmer, A. Leila and E. Yassin (1987) "Bureaucratic Rigidity and Economic Development in the Middle East: A Study of Egypt, Sudan, and Saudi Arabia", International Review of Administrative Sciences, 53, pp. 241-257.

Al-Husseiny, Aisha (1990) "Female Administrative Leadership in Higher Education in Saudi Arabia: Preparation and Development", In Ahmed Hassan Dahlan (Ed.), Politics, Administration and Development in Saudi Arabia, pp. 183-196. Saudi Arabia: Dar Al-Shoroug.

Al-Sabhan, M., Abdullah (1972) Changing Organizations within a Changing Society: Saudi Arabia. Unpublished Master's Thesis, University of Arizona.

Al-Sadhan, M.Abdurrahman (1980) "The Modernization of the Saudi Bureaucracy", In Willard A. Beling (Ed.), King Faisal and The Modernization of Saudi Arabia, pp. 7589, The United Kingdom: Groom Helm Ltd.,

Al-Sadhan, Abdulrahman (1982) "Poor Working Habits", Civil Service Journal, 52, pp. 17-19.

Al-Saeeri, A., Amir (1993) Employee Performance and Cultural Configuration: An Analysis of Three Saudi Arabian Public Corporations' Cultures and Performance. Unpublished Doctoral Dissertation, Virginia Commonwealth University.

Al-Saigh, N. (Ed). (1986) "Public Administration and Administrative Reform", In N. Al-Saigh (Ed.), Administrative Reform in the Arab World: Readings. Amman, Jordan: Arab Organization of Administrative Sciences, pp. 13-43.

Al-Zamel, Abdullah and Abdul Monem Khattab. (1983) "A Study of the Incentive Systems in the Saudi Civil Service", Public Administration, 39, Oct. 1983, pp. 7-75.

Assad, W. Soraya. (1977) Role Demands of Professional Women in Jeddah, Saudi Arabia. Unpublished Master's Thesis. Portland State University.

Assad, W. Soraya. (1983) Women and Work in Saudi Arabia: A Study of Job Satisfaction in Higher Education, Unpublished Doctoral Dissertation, Colorado State University.

Assad, W. Soraya (1989) "Current Status of Literature on Muslim Women: A Case Study", Journal Institute of Muslim Minority Affair, 10, No. 1, pp. 171-198.

Bills, D. (1990) "Employer's Use of Job History Data for Making Hiring Decision: A Fuller Specification of Job Assignment and Status Attainment", The Sociological Quarterly, 31, No.1, pp. 23-35.

Bittel, R. Lester and John W. Newstrom (1990) What Every Supervisor Should Know. USA: McGraw-Hill Inc.

Borman, W., M. Hanson and Jerry Hedge (1997) "Personnel Selection", Annual Review Psychology, 48, pp. 229-337.

Bukhary-Haddad, M. (1986) Administrative Training for Development: A Survey Study of the In-Service Administrative Training Programs in Saudi Arabia, Unpublished Doctoral Dissertation, University of Pittsburgh.

Comstock, W. Thomas (1987) Modern Supervision. USA: Delmar Publishers Inc.

Cummings, L. L. and D. Schwab (1973) Performance in Organization: Determinants and Appraisal. Glenview: Scott, Foreman.

Dhaher, Ahmed (1979) "Bureaucracy and Social Alienation: the Case of King Abdulaziz University", King Abdulaziz University Journal, College of Economics and Administration, No.9, pp. 22-40.

Ghosheh, Zaki R. (1983) Ethics in Public Administration, Amman, Jordan: Al-Sharg.

Jammaz, Saud (1973) Riyadh University: Historical Foundations, Current Status, Critical Problems, and Suggested Solutions. Unpublished Doctoral Dissertation, University of Southern California, 
Jreisat, J.E. (1988) "Administrative Reform in Developing Countries: A Comparative Perspective", Public Administration and Development, 1, pp. 85-97.

Jreisat, J. E. (1991) "Bureaucrats of the Arab World: Incompatible Influences", In A. Farazmand (Ed.), Handbook of Comparative and Development Public Administration, pp. 665-675. New York: Marcel Deckker.

Kostiuk, P. and D. Follmann (1989) "Learning Curves, Personal Characteristics, and Job Performance", Journal of Labor Economics, 7, No. 2, pp. 129-146.

Lawler III, E.Edward (1973) Motivation in Work Organizations, Monteray, Calif.: Brooks/Cole.

Miner, John B., (1969) Personal Psychology. London, Collier: Macmillan Limited.

Ministry of Planning, Fifth Development Plan Strategy, Riyadh, Saudi Arabia:, 1990-1995.

Ministry of Planning, Sixth Development Plan Strategy, Riyadh, Saudi Arabia, 1995-2000.

Moore, Scott., (1987) "The theory of Street-Level Bureaucracy: A Positive Critique", Administration and Society, 19, No. 1, pp. 74-94.

Murshid, A. Talal (1978) Saudi Arabia: Administrative Aspects of Development. Unpublished Doctoral Dissertation, Claremont Graduate School.

Nash, Michael (1985) Making People Productive. San Francisco: Jossey-Bass Publishers.

Rawaf, Monira (1990) "The changing status of women in management in the public administration of Saudi Arabia", Public Administration and Development, 10, pp. 209-219.

Reilly, Wyn (1979) Training Administrators for Development: An Introduction for Public Servants and Government Training Officers. London: Heinemann Educational Book Ltd.

Russell, S. James, James R. Terborg and Mary L. Powers (1985) "Organizational Performance and Organizational Level Training and Support", Personnel Psychology, 4, No.38 Winter (1979), pp. 849-863.

Saks, M. Alan (1996) "The Relationship between the Amount and Helpfulness of Entry Training and work Outcomes", Human Relations, 49, No.4, pp. 429-451.

Savas, E. S. and S. G. Ginsburg (1973) "The Civil Service: A Meritless System?", The Public Interest, 32 Summer, pp. 70-85.

Schein, Edgar H., (1965) Organizational Psychology, Englewood Cliffs, New Jersey: PrenticeHall, Inc.

Schoen, H. Sterling and Douglas E. Durand (1979) Supervision: The Management of Organizational Resources. Englewood Cliffs: Prentice Hall, Inc.

Tawati, Ahmed. M. (1976) The Civil Service of Saudi Arabia: Problems and Prospects. Unpublished Doctoral Dissertation, West Virginia University.

Weiss, W. H. (1997) "Promoting Quality through Training and Employee Performance", Supervision, 58, No. 7, (July 1997), pp. 3-6.

Yousef, Awatif A. (1981) Administrative Problems in Higher Education: Comparative Study of Arab Republic of Egypt and Saudi Arabia, Unpublished Masters Thesis, Helwan University, Cairo, Egypt. 
في تنمية القوى البشرية : اختيار الموظف والتدريب

$$
\text { ( دراسة لأعضاء الجهاز الإداري النسائي في إحدى مؤسسات التعليم العالي }
$$$$
\text { بالمملكة العربية السعودية) }
$$$$
\text { ثريا ولي الدين أسعد }
$$

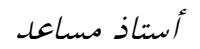

قسم الاجتماع - كلية الآداب والعلوم الإنسانية

جامعة الملك عبدالعزيز - جلة - المملكة العبلة الادبية السعودية الإنسانية

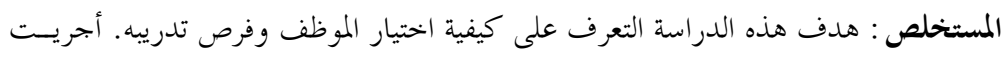

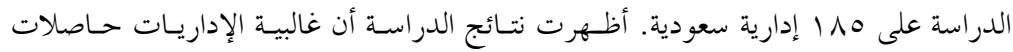

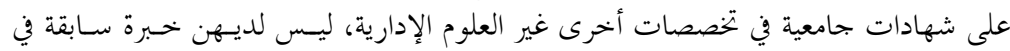

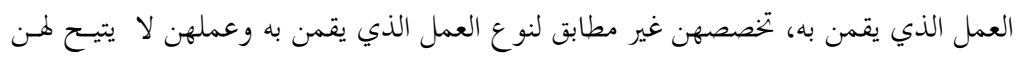

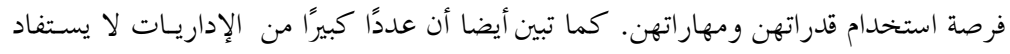

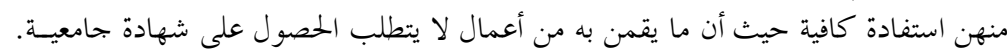

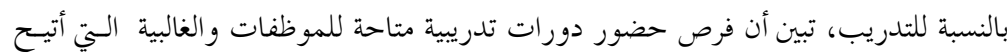

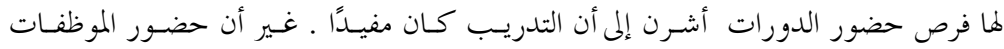

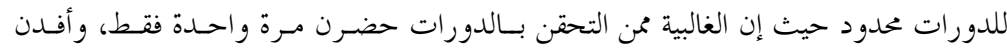

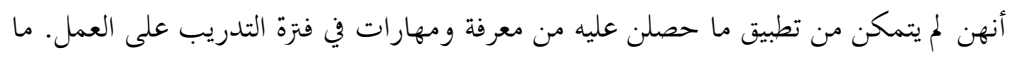

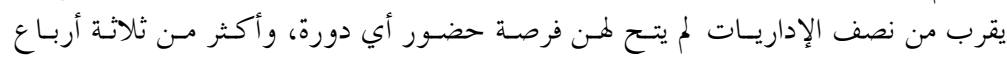

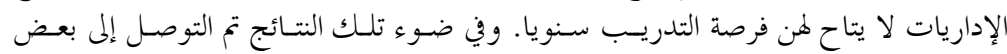

